\title{
Perencanaan Sistem Plambing Air Bersih Gedung Dinas Lingkungan Hidup Propinsi Jawa Barat.
}

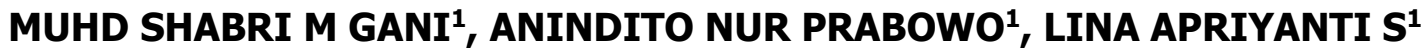

\author{
1. Jurusan Teknik Lingkungan Fakultas Teknik Sipil dan Perencanaan \\ (Institut Teknologi Nasional Bandung) \\ Email :muhdshabri7@gmail.com
}

\begin{abstract}
ABSTRAK
Sistem Pemerintahan yang semakin berkembang mengakibatkan gedung Dinas Lingkungan Hidup (DLH) Propinsi Jawa Barat saat ini mempunyai kapasitas dan fasilitas yang belum memadai untuk melaksanakan semua aktivitas secara terpadu. Sehingga diperlukannya tambahan sarana penunjang yaitu area untuk pendukung aktivitas kerja maka, pemerintah propinsi merencanakan untuk mengembangkan gedung perkantoran DLH Propinsi Jawa. Kegiatan sanitasi dalam gedung harus ditunjang dengan pemenuhan akan kebutuhan air bersih bagi semua penghuni, maka dari itu dibutuhkan perencanaan sistem plambing air bersih. Metode yang menjadi acuan adalah SNI 7065-2005, untuk perhitungan kebutuhan air bersih dan SNI 8153-2015 untuk penentuan dimensi pipa air bersih. Hasil perhitungan jumlah populasi menunjukan 654 jiwa. Total kebutuhan air bersih : 38,1 $\mathrm{m}^{3} / \mathrm{hari}$, Kapasitas tangki bawah : 45,72 $\mathrm{m}^{3}$, kapasitas tangki atas : 15,29 $\mathrm{m}^{3}$. Berdasarkan hasil perencanaan dimensi pipa horizontal air bersih berkisar antara rentang 15 - $32 \mathrm{~mm}$, dimensi pipa vertikal $40 \mathrm{~mm}$, pompa yang dipasang adalah pompa sentrifugal dengan daya : 1,02 kW. Pompa booster dipasang untuk membantu tekanan di lantai 6 karena tidak memenuhi tekanan standar. Pipa yang digunakan untuk distribusi air bersih adalah jenis pipa PPR (Polypropylene Random).
\end{abstract}

Kata kunci: Air Bersih, Alat Plambing Dan pipa PPR

\begin{abstract}
A system of gevornment which keeps growing resulting in the office building of environmental dlh) the provinces of west java currently possess the capacity and to inadequate facilities in carrying out all the activity of in an integrated way. So that she needed addition support facilities for that is an area for work and supporting the activity of, the provincial government of planning to develop java topped dlh office buildings. Sanitation in the building activities must be supported with the fulfilment of not need clean water for all the inhabitants of the, that is why it is planning plambing system needed clear water. $A$ method which is used to is 7065-2005 sni, to requetment calculation sni 8153-2015 clear water and clear water pipe for the determination of dimensions. The result of reckoning the size of the population show 654 soul. The total the need of clean water 38,1 $\mathrm{m}^{3}$ per day, the capacity of a tank under $45,72 \mathrm{~m}^{3}$, the capacity of a tank upon the request from has set the inflation rate. Based on the results of planning dimensions horizontal. Pipa clear water ranges between ranges
\end{abstract}

Keywords: Water Supply And Plumbing Equipment. 


\section{PENDAHULUAN}

Menurut Peraturan Walikota Bandung Nomor 1023 tahun 2016 Tentang Bangunan Gedung Hijau bahwa bangunan gedung yang bertanggung jawab terhadap sumber daya yang efisien dari sejak perencana, pelaksanaan, kontruksi, dan pemeliharaan. Salah satu yang dapat ditimbulkan dari suatu pembangun adalah bertambahnya kebutuhan air dan meningkatnya volume limbah domestik yang akan dihasilkan. Fungsi dan peralatan plambing adalah untuk menyediakan air bersih ke tempat-tempat yang memerlukan air bersih dengan tekanan yang cukup.

Perencanaan plambing air bersih ini mengaju kepada Peraturan Walikota Bandung Tentang Bangunan Gedung Hijau Nomor 1023 tahun 2016 tentang koefisien air yang aspek penggunaan peralatan saniter hemat air. Lokasi pembangunan terdapat di Jalan Rancanumpang, Kelurahan Rancanumpang, Kecamatan Gedebage, Kota Bandung diatas lahan seluas $735.277 \mathrm{~m}^{2}$ dan luas bangunan $223.616 \mathrm{~m}^{2}$. Perencanaan untuk gedung perkantoran DLH Propinsi Jawa Barat terdiri dari 6 lantai.

\section{METODOLOGI}

Perencanaan plambing air bersih dengan penggunaan pearalatan saniter hemat air pada Gedung Dinas Lingkungan Hidup Propinsi Jabar dibagi dalam beberapa tahapan dilihat pada Gambar 1 Tahap Perencanaan.

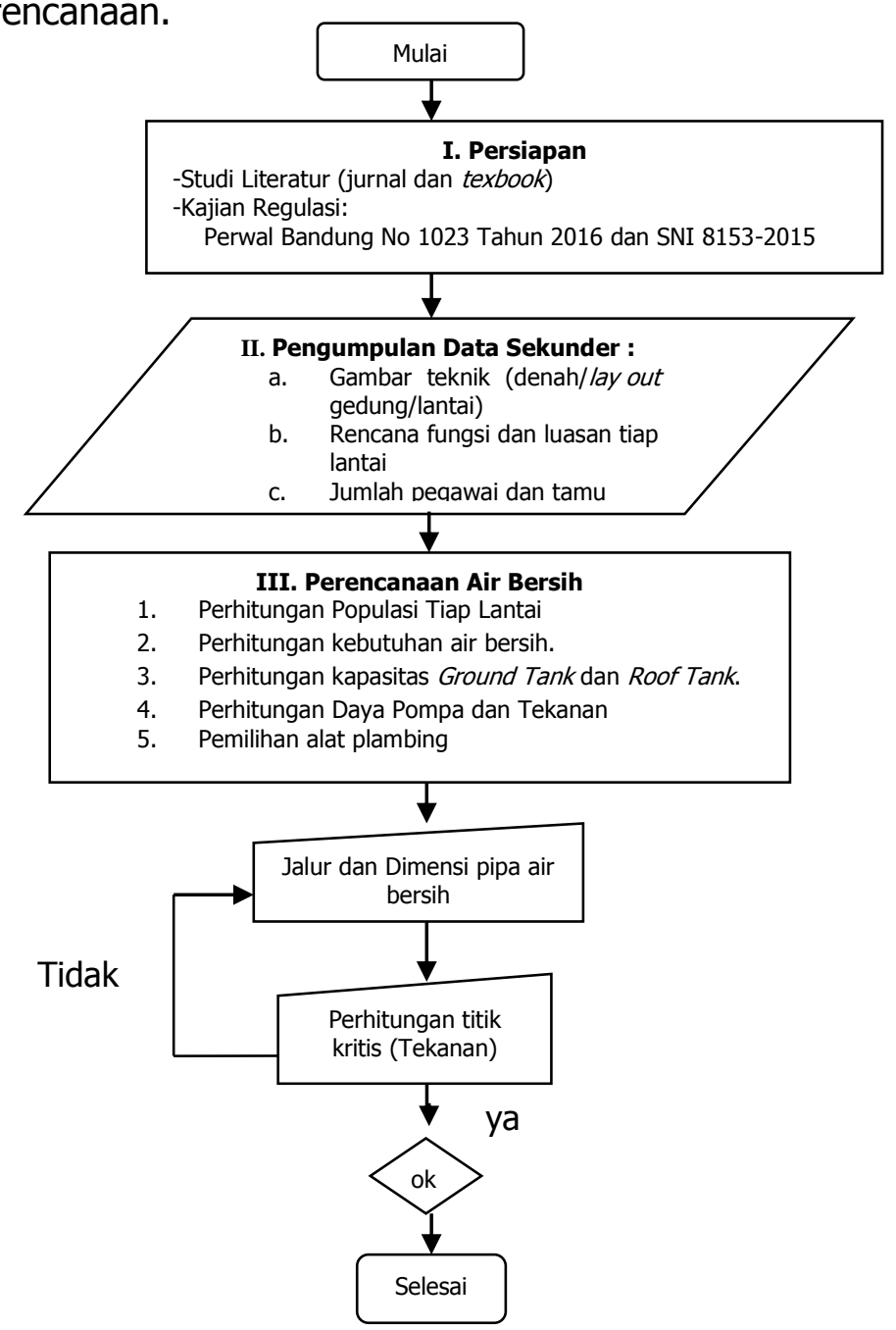

Gambar 1. Tahap Perencanaan. 
Perencanaan sistem plambing pada pembangunan gedung ini dilakukan dengan cara:

\section{Persiapan}

Melakukan tinjauan pustaka mengenai teori-teori yang berhubungan dengan sistem plambing dan dasar-dasar perencanaan sistem plambing serta mempelajari tentang konsep bangunan gedung hijau mengacu kepada Peraturan Walikota Bandung No 1023 Tahun 2016 tentang, dan SNI 8153-2015 tentang sistem plambing pada bangunan gedung.

\section{Pengumpulan Data Sekunder}

Data yang diambil yaitu :

a. Denah gedung dan kondisi eksisting sekitar daerah perencanaan.

Untuk mengatahui kondisi eksisting dari sekitar pembangunann gedung seperti jalur pelayanan air bersih dan saluran drainase.

b. Fungsi tiap lantai.

Untuk menerangkan keadaaan gedung seperti jumlah lantai, fungsi lantai, luas tiap ruangan untuk menghitung jumlah populasi dan merencanakan jalur pipa yang direncanakan.

III. Perencanaan air bersih terdiri dari :

1. Menghitung populasi gedung.

Untuk mengetahui kebutuhan air bersih pada gedung DLH Propinsi jawa Barat, perlu diketahui jumlah populasi terlebih dahulu dalam memperkirakan jumlah populasi diperlukan perhitungan menggunakan rumus berdasarkan (Noerbambang, 2005):

\section{Keterangan}

$$
\text { populasi (jiwa) }=\frac{\text { Luas efektif ruang }(\%)}{\text { Beban Hunian }}
$$

Beban Hunian = luas pergerakan untuk 1 orang dalam ruangan.

Luas efektif = luas ruangan yang di gunakan. $\left(\%, m^{2}\right)$

2. Menghitung kebutuhan air bersih.

Kebutuhan air bersih dihitung berdasarkan jumlah populasi yang terdapat pada gedung ini. Dengan mengetahui pemakaian air rata-rata per orang per hari maka akan di ketahui jumlah kebutuhan air bersih dalam sehari. Berikut merupakan Tabel pemakaian air berdasarkan Noerbambang dan Morimura tahun 2005:

$\mathrm{Q}\left(\mathrm{m}^{3} /\right.$ hari) = Jumlah populasi (jiwa) $\mathrm{x}$ standar pemakaian air besih (liter/orang/hari)

3. Perhitungan kapasitas Ground Tank dan Roof Tank.

Untuk mencari kapasitas ground tank perlu diketahui terlebih dahulu total kebutuhan air bersih dan mengkalikan dengan faktor keamanan 20\% untuk mengatasi masalah kebocoran (Noerbambang, 2005).

Untuk melakukan perhitungan volume ground tank (VGT) dengan Q perhari dilakukan dengan cara menggunakan rumus (Noerbambang, 2005):

VGT $\left(m^{3}\right)=$ (Total air bersih $\mathrm{x}$ (Safety factor $)+$ Total air bersih)

$$
V=p \times l \times t
$$

Selanjutnya setelah mendapatkan volume ground tank, perlu dilakukan perhitungan kapasitas ground tank untuk melayani jam puncak pada gedung DLH Propinsi Jawa Barat dengan menggunakan rumus berdasarkan (Noerbambang, 2005): 
Dimana :

$$
\begin{aligned}
& \mathrm{Qr}=\frac{\text { volume ground tank }}{\text { jam kerja }} \\
& >\mathrm{Qp}=\mathrm{Qr} \times \mathrm{C}_{1} \\
& >\mathrm{Qmak}=\mathrm{Qp} \times \mathrm{C}_{2}
\end{aligned}
$$

VGT = Volume ground tank

$>\mathrm{Qr}=$ Debit rata-rata $\left(\mathrm{m}^{3} / \mathrm{jam}\right)$

$>\mathrm{C}_{1}=$ faktor jam puncak merupakan debit puncak pemakaian selama 1 jam dalam 1 hari $(1,5-2)$

$>\mathrm{C}_{2}=$ faktor menit puncak merupakan debit puncak pemakaian air selama 1 menit dalam 1 jam (3 - 4)

$>\mathrm{Qp} \quad=$ kebutuhan jam puncak

$>$ Qmax = kebutuhan menit puncak

4. Perhitungan Daya Pompa dan Tekanan

Rumus untuk menghitung efisiensi pompa (Ir. Sularso, 1987):

Dimana :

$$
\mathbf{P}=\frac{\rho . \mathrm{g} \cdot \mathrm{Q} . \mathrm{H}}{80 \%}
$$

$>\mathrm{P} \quad=$ Daya pompa (watt)

$>\rho=$ Massa jenis air $\left(998,23 \mathrm{~kg} / \mathrm{m}^{3}\right.$ untuk suhu $\left.20^{\circ} \mathrm{C}\right)$

$>\mathrm{g}=$ Percepatan gravitasi $\left(9,8 \mathrm{~m} / \mathrm{s}^{2}\right)$

$>\mathrm{Q} \quad=$ kapasitas pompa $\left(\mathrm{m}^{3 /}\right.$ detik)

$>\mathrm{H} \quad=$ head total $(\mathrm{m})$

$>80 \%=$ efesiensi pemompaan.

5. Pemilihan alat plambing

Kebutuhan alat plambing dihitung berdasarkan jumlah populasi maksimum setiap lantai perhari.

6. Jalur Dan Dimensi Pipa Air Bersih

Menentukan jalur pipa air bersih dengan efektif dan efisien berdasarkan denah dari setiap lantai pada gedung DLH Propinsi Jawa Barat, selanjutnya penentuan diameter pipa air bersih berdasrkan unit beban alat plambing SNI SNI-8153-2015 dan Perancangan dan Pemeliharaan Sistem Plambing (Soufyan M. Noerbambang, 2005).

7. Perhitungan Titik Kritis (Tekanan).

Untuk mengetahui kehilangan tekanan energi ( head total) pada pipa outlet dari ground tank, perlu dilakukan perhitungan tekanan. Perhitungan tekanan kehilangan energi (head tota) dapat dilakukan dengan cara (Noerbambang, 2005):

Head total $=($ head elevasi + headloss + head kecepatan + Tekanan awal $)$ Keterangan :

- Head elevasi = Perbedaan Elevasi Pipa

- Head loss = Kerugian Gesek Pipa

- Head kecepatan = Kecepatan Aliran Air

\section{HASIL DAN PEMBAHASAN}

\subsection{Kondisi Eksisting}

Gedung Dinas Lingkungan Hidup Propinsi Jawa Barat merupakan gedung yang berfungsi sebagai pelayanan masyarakat. Lokasi dari gedung DLH propinsi jawa barat ini berada di Jalan Rancanumpang, kecamatan Gedebage, kota Bandung Jawa Barat. Gedung Dinas Lingkungan Hidup Propinsi Jawa Barat merupakan gedung yang memiliki 6 lantai. Adapun 
peruntukannya yaitu 1 lantai untuk gedung serbaguna, 6 lantai ruang kerja dan ruang rapat, lantai 5 untuk laboratorium. Dengan luas lahan $735.277 \mathrm{~m}^{2}$ dan luas bangunan $223.616 \mathrm{~m}^{2}$.

\subsection{Perhitungan Populasi}

Perencanaan plambing suatu gedung terlebih dahulu harus memperkirakan jumlah total populasi maksimal yang berada didalam gedung. Hal tersebut berfungsi untuk mengetahui jumlah kebutuhan air agar tidak mengalami kekurangan pada saat operasi. Jumlah populasi dapat diketahui dari data lapangan yang didapatkan dan data luas area berdasarkan literatur dari Neufert 2002. Jumlah populasi contoh ruang kerja staf pada gedung DLH ini adalah sebagai berikut:

- $\quad$ Luas efektif. = Luas kerja staf $\mathrm{x}$ efektifitas ruangan.

$=70 \mathrm{~m}^{2} \times 80 \%=56 \mathrm{~m}^{2}$

- $\quad$ Jumlah populasi $=$ Luas efektif $x$ standar luasan per-orang

$=56 \mathrm{~m}^{2} \times 10 \mathrm{~m}^{2} / \mathrm{jiwa}=6$ orang.

- Jumlah kebutuhan 1 lantai + jumlah kapsitas orang setiap ruangan.

Tabel 1 Perhitungan Jumlah Populasi

\begin{tabular}{|c|c|c|c|}
\hline Lantai & Tamu & Pegawai & $\begin{array}{c}\text { Jumlah } \\
\text { Populasi } \\
\text { (Jiwa) }\end{array}$ \\
\hline Lantai 1 & 180 & 32 & 212 \\
\hline Lantai 2 & 32 & 29 & 61 \\
\hline Lantai 3 & 18 & 78 & 96 \\
\hline Lantai 4 & 17 & 97 & 114 \\
\hline Lantai 5 & 2 & 74 & 76 \\
\hline Lantai 6 & 17 & 78 & 95 \\
\hline \multicolumn{3}{|c|}{ Jumlah Populasi } & 654 \\
\hline
\end{tabular}

Sumber : Hasil Perhitungan, 2017

Keterangan : jumlah tamu 266

: pegawai 388

Jumlah populasi di kantor Dinas Lingkungan Hidup Propinsi Jawa Barat yaitu 654 jiwa.

\subsection{Kebutuhan Air Bersih Berdasarkan Populasi}

Kebutuhan air pada kantor Dinas Lingkungan Hidup Propinsi Jawa Barat berdasarkan jumlah, pegawai dan tamu terhadap standar kebutuhan air berdasarkan SNI 03-7065-2005 pada tabel 1. Standar kebutuhan air/pegawai/hari menggunakan kebutuhan air untuk pegawai kantor yaitu 50 L/pegawai/hari. Untuk lantai 1 gedung serba guna standart 25 L/kursi. Total kebutuhan air bersih untuk kantor Dinas Lingkungan Hidup Propinsi Jawa Barat adalah $38.122 \mathrm{~L} /$ Hari atau 38,1 $\mathrm{m}^{3} / \mathrm{L}$.

$$
\begin{gathered}
\mathrm{Q}\left(\mathrm{m}^{3} / \text { hari }\right)=\text { Jumlah populasi (jiwa) } \times \text { standar pemakaian air besih (liter/orang/hari) } \\
=6 \text { orang } \times 50 \text { liter/orang/hari }=300 \text { liter/hari }
\end{gathered}
$$

\subsection{Perhitungan Kapasitas Tangki Bawah (Ground Water Tank)}

Ground Water Tank (GWT) berfungsi sebagai penyediaan air bagi reservoir atas yang kemudian pada akhirnya akan didistribusikan kepada pemakai. Oleh sebab pemakaian air selama sehari yang telah diketahui, maka reservoir bawah harus dapat menampung kebutuhan dalam satu hari. Namun selama pemakaian, reservoir bawah secara simultan akan mengalami pengisian dari sumur dalam (deep well). Berikut adalah perhitungan volume penyediaan air untuk reservoir bawah:

$$
\text { VGT }=\text { Total air bersih } x \text { (Safety factor) }
$$




$$
\begin{aligned}
& \text { VGT }=\text { Volume Ground Tank } \\
& \text { Safety factor }=20 \% \\
& =\left(38,1 \mathrm{~m}^{3} / \text { hari } \times 1,2\right)=45,72 \mathrm{~m}^{3} / \text { hari }
\end{aligned}
$$

Dari hasil perhitungan kapasitas tangki bawah didapat volume tangki bawah sebesar 45,72 $\mathrm{m}^{3} /$ hari.

$$
V=p \times l \times t
$$

Dari hasil perhitungan kapasitas tangki bawah didapat volume tangki bawah sebesar 45,72 $\mathrm{m}^{3} /$ hari berbentuk rectangular dengan dimensi panjang (p) sebesar $3 \mathrm{~m}$, lebar (I) sebesar 4 $\mathrm{m}$ dan ketinggian $(\mathrm{t})$ sebesar 3,9 m.

\subsection{Perhitungan Volume Reservoir Atas (Roof Tank)}

Reservoir atas berfungsi menampung air untuk kebutuhan puncak dan disediakan dengan kapasitas cukup selama jangka waktu kebutuhan puncak terjadi. jangka waktu yang dianggap cukup untuk pemakaian jam puncak pada kantor adalah 1 jam (Tp). Pada saat bersamaan diperlukan pengisian tangki yang lebih cepat jangka waktunya dibandingkan jangka waktu pemakaiannya, oleh karena itu, waktu pengisian tangki ditetapkan selama 0,5 jam (TPU). Dengan demikian maka volume reservoir atas dapat dihitung menggunakan rumus berdasrkan (Noerbambang,2005):

$$
\begin{aligned}
& \mathrm{Qr}=\frac{\text { volume ground tank }}{\text { jam kerja }} \\
& >\mathrm{Qp}=\mathrm{Qr} \times \mathrm{C} 1 \\
& >\mathrm{Qmak}=\mathrm{Qp} \times \mathrm{C} 2
\end{aligned}
$$

\section{Dimana :}

$>$ VGT $=$ Volume ground tank

$>$ Qr $=$ Debit rata-rata $\left(\mathrm{m}^{3} / \mathrm{jam}\right)$

$>\mathrm{C} 1=$ faktor jam puncak merupakan debit puncak pemakaian selama 1 jam dalam 1 hari $(1,5-2)$

$>\mathrm{C} 2=$ faktor menit puncak merupakan debit puncak pemakaian air selama 1 menit dalam 1 jam (3 - ‘4)

$>\mathrm{Qp} \quad=$ kebutuhan jam puncak

$>\mathrm{Qmax}=$ kebutuhan menit puncak

$$
V e=(Q p-Q m a x) \times T p+Q p u \times T P U
$$

Keterangan :

$>\mathrm{Ve} \quad=$ kapasitas efektif tanki atas (L)

$>\mathrm{QP} \quad=$ kebutuhan jam puncak $\left(\mathrm{m}^{3} / \mathrm{jam}\right)$

$>\mathrm{Qmax}=$ kebutuhan menit puncak $\left(\mathrm{m}^{3} / \mathrm{jam}\right)$

$>\mathrm{Tp} \quad$ = jangka waktu kebutuhan puncak (jam)

$>\mathrm{Qpu}=$ kapasitas pompa pengisi $\left(\mathrm{m}^{3} / \mathrm{jam}\right)$

$>$ TPU = jangka waktu kerja pompa pengisi (jam)

Berdasarkan rumus di atas diapat dihitung kapasitas volume tangki atas
$>$ Volume ground tank $=45,7 \mathrm{~m}^{3}$
$>\mathrm{T}$ (waktu kerja) $\quad=8$ jam
$>\mathrm{C} 1$
$=2$
$>\mathrm{C} 2$
$=3$
$>\mathrm{Qr}$
$>\mathrm{Qp}$
$=\frac{45,7 \mathrm{~m}^{3}}{8 \mathrm{jam}}=5,71 \frac{\mathrm{m}^{3}}{\mathrm{jam}}$
$>$ Qmax
$=5,71 \frac{\mathrm{m}^{3}}{j a \mathrm{~m}} \times 2=11,4 \frac{\mathrm{m}^{3}}{\mathrm{jam}}$
$>\mathrm{Tp}$
$=5,71 \frac{\mathrm{m}^{3}}{\mathrm{jam}} \times 3=17,13 \frac{\mathrm{m}^{3}}{\mathrm{jam}}$
$>$ TPU
$=1$ jam (asumsi pada saat jam istirahat)
$=0,5 \mathrm{jam}$
Maka, nilai $V_{e}$ adalah : 
$\mathrm{V}_{\mathrm{e}} \quad=\left[11,4 \frac{\mathrm{m}^{3}}{\mathrm{jam}}-17,13 \frac{\mathrm{m}^{3}}{\mathrm{jam}}\right] \times 1 \mathrm{jam}+17,13 \frac{\mathrm{m}^{3}}{\mathrm{jam}} \times 0,5 \mathrm{jam}=15,29 \mathrm{~m}^{3}$

\subsection{Perhitungan Daya Pompa}

Daya pompa adalah tenaga yang dibutuhkan untuk mengalirkan air. Untuk menghitung daya pompa perlu mengetahui headstatis dan juga headloss dari pipa. Berikut adalah perhitungan untuk mendapatkan daya pompa Ground Water Tank menuju Roof Tank.

$$
\mathrm{P}=\frac{\rho . \mathrm{g} \cdot \mathrm{Q} \cdot \mathrm{H}}{80 \%}
$$

Dimana :



Dimana :

$>\mathrm{H}=$ head total pompa

$>\mathrm{Ha}=$ head statis pompa

$>\Delta \mathrm{hp}=$ perbedaan tekanan pada kedua permukaan

$>\mathrm{Hl}=$ kehilangan yang keluar $(\mathrm{m})$

$>\mathrm{G} \quad=$ kecepatan gravitasi $\left(9,81 \mathrm{~m} /\right.$ detik $\left.^{2}\right)$

Perhitungan kapsitas pompa yang akan di gunakan di Kantor Dinas Lingkungan Hidup Propinsi Jawa Barat:

1. Kapasitas pompa

Untuk mengetahui berapa besarnya kapsitas pompa, dapat dilihat pada perhitungan kapasitas volume tangki atas. Besarnya kapasitas pompa sebesar 33,15 l/menit atau $0,0038 \mathrm{~m}^{3} /$ detik

2. Head statis

Head statis adalah perbedaan ketinggian (elevasi) dari sisi keluar (akhir proses) pompa dengan sisi hisap pompa. Pipa tangki bawah menuju ke tangki atas di dapatkan sebesar $26 \mathrm{~m}$. 




Gambar 2 Skematik Air Bersih dan Tinggi Gedung.

3. Diameter pompa

Diameter pompa ini digunakan untuk mengalirkan air dari tangki bawah menuju tangki atas. Untuk mengetahui nilai diameter pipa yang dibutuhkan untuk mengalirkan air dari bawah ke atas harus dilakukan perhitungan dengan rumus :

$>\mathrm{V}=$ Kecepatan alirian air $1,5 \mathrm{~m} / \mathrm{s}$ (Noerbambang,2005)

$>\mathrm{A}=\frac{Q}{V}=\frac{0,0038 \frac{\mathrm{m}^{3}}{\mathrm{~s}}}{1,5 \frac{\mathrm{m}}{\mathrm{s}}}=0,0025 \mathrm{~m}^{2}$

$>\mathrm{A}=\frac{1}{4} x \pi x d^{2}$

$>\mathrm{d}=\sqrt{\frac{A \times 4}{\pi}}=\sqrt{\frac{0,0025 \times 4}{\pi}}=0,055 \mathrm{~m}=55 \mathrm{~mm}$ diameter pasaran $63 \mathrm{~mm}$

4. Head loss (hf total)

Untuk menghitung kerugian gesek di dalam pipa dapat di pakai rumus sebagai berikut :

$\begin{array}{ll}>\mathrm{HI} & =6,05 \times\left(\frac{Q^{1,85}}{C^{1,85} \mathrm{~d}^{4,87}}\right) \times 10^{5} \\ >\mathrm{HI} & =6,05 \times\left(\frac{33,15^{1,851} / \mathrm{menit}^{1}}{130^{1,85} \times 63^{4,87} \mathrm{~mm}}\right) \times 10^{5}=0,00083 \mathrm{bar}=0,83 \mathrm{~m}\end{array}$

5. Kecepatan aliran sebenarnya

$$
\begin{aligned}
& >\mathrm{A}=\frac{1}{4} \times \pi x d^{2} \\
& >\mathrm{A}=\frac{1}{4} \times \pi x(0,055 \mathrm{~m})^{2}=0,0023 \mathrm{~m}^{2} \\
& >\mathrm{V}=\frac{Q}{A}=\frac{0,0038 \frac{\mathrm{m}^{3}}{\mathrm{~s}}}{0,0023 \mathrm{~m}^{2}}=1,65 \frac{\mathrm{m}}{\mathrm{s}}
\end{aligned}
$$


6. Head Velocity

Head karena perbedaan tekanan pada kedua permukaan $(\Delta h p)$. Untuk mengetahui dapat dinyatakan dengan rumus:

$$
\begin{aligned}
>\mathrm{Hv} & =\frac{v^{2}}{2 \times \mathrm{g}} \\
>\mathrm{Hv} & =\frac{1,65^{2} \mathrm{~m} / \mathrm{s}}{2 \times 9,81 \mathrm{~m} / \mathrm{s}}=0,138 \mathrm{~m}
\end{aligned}
$$

7. Head Total

Head total adalah besarnya head minimal yang harus disediakan oleh pompa untuk dapat mengalirkan air sesuai dengan kondisi yang diinginkan. Dapat dihitunga dengan rumus:

$\mathrm{H}=\mathrm{ha}+\mathrm{Hv}+\mathrm{h} f$ total

$H=26 m+0,138 m+0,83 m=26,968 m$

8. Daya Pompa

Pompa di gunakan untuk menaikan air dari tangki atas melalui sistem perpipaan. Dapat dihitung dengan rumus:

$$
\mathrm{P}=\frac{1000^{\mathrm{kg}} / \mathrm{m}^{3} \times 9,81 \mathrm{~m} / \mathrm{s} \times 0,0038 \mathrm{~m}^{3} / \text { detik } \times 21,968 \mathrm{~m}}{80 \%}=1023 \mathrm{watt}=1,02 \mathrm{~kW}
$$

Daya pompa yang dibutuhkan pompa yang bekerja untuk distribusi ke semua lantai adalah $1,02 \mathrm{~kW}$.

\subsection{Perhitungan Sisa Tekanan}

Dalam perhitungan tekanan atau titik kritis, dilakukan dengan cara menentukan titik kritis pada lantai 5 dan lantai 6 . Titik kritis di lantai 6 yaitu alat plambing yang ada ujung pipa adalah lavatory dengan diameter pipa adalah $20 \mathrm{~mm}$, yaitu kurang tekanan lantai 6 sebesar 0,66 bar dan lantai 5 sebesar 0,29 bar. Perbedaan tinggi setiap lantai sebesar 3,5 m.

\subsection{Perhitungan Daya Pompa Booster}

pompa booster di gunakan untuk menyalurkan air bersih dari reservoir atas ke alat-alat plambing yang berada di lantai 5 dan lantai 6 . Untuk mengetahui daya pompa yang diperlukan maka perlu diketahui jumlah alat plambing yang akan di layani kemudian didapat jumlah unit beban alat plambing. Berikut ini unit beban alat plambing air bersih:

Tabel 2. Unit beban alat plmbing air bersih untuk UBAP

\begin{tabular}{cccc}
\hline Jenis Alat & Jumlah Alat Plambing & $\begin{array}{c}\text { UBAP/ Jenis Alat } \\
\text { Plambing }\end{array}$ & $\begin{array}{c}\text { Jumlah } \\
\text { UBAP }\end{array}$ \\
\hline Faucet (FC) & 2 & 3 & 6 \\
Lavatori (LV) & 8 & 1 & 8 \\
Water Closet (WC) & 9 & 2,5 & 22,5 \\
Urinoir (UR) & 6 & 2 & 12 \\
Kitcnh sink (ks) & 1 & 3 & 3 \\
\hline \multicolumn{4}{c}{ jumlah } \\
\hline Sumber : SNI 8153-2015 & $\mathbf{5 1 , 5}$ \\
Keterangan : UBAP (unit beban alat Plambing)
\end{tabular}

Dari tabel di atas maka diketahui jumlah unit beban alat plambing di lantai 5 dan lantai 6 adalah 51,5. Unit beban alat plambing tersebut kemudian di plotkan grafik SNI 8153-2015 hubungan antara unit beban alat plambing dengan kebutuhan air. maka didapatkan kebutuhan air sebesar $193 \mathrm{l} /$ menit atau 0,032 $\mathrm{m}^{3} /$ detik. Sehingga daya pompa yang di butuhkan.

1. Head statis $(\mathrm{Ha})$ 
Head statis adalah perbedaan ketinggian (elevasi) dari sisi keluar (akhir proses) pompa dengan sisi hisap pompa. Pipa tangki bawah menuju ke tangki atas di dapatkan sebesar 10,12 m.

2. Diameter pompa

Diameter pompa ini digunakan untuk mengalirkan air dari tangki bawah menuju tangki atas. Untuk mengetahui nilai diameter pipa yang dibutuhkan untuk mengalirkan air dari bawah ke atas harus dilakukan perhitungan dengan rumus :

$>\mathrm{V}=$ Kecepatan alirian air $1,5 \mathrm{~m} / \mathrm{s}$ (Noerbambang,2005)

$>\mathrm{A}=\frac{Q}{V}=\frac{0,032 \frac{m^{3}}{s}}{1,5 \frac{m}{s}}=0,021 \mathrm{~m}^{2}$

$>\mathrm{A}=\frac{1}{4} x \pi x \mathrm{~d}^{2}$

$>\mathrm{d}=\sqrt{\frac{A \times 4}{\pi}}=\sqrt{\frac{0,021 \times 4}{\pi}}=0,16 \mathrm{~m}=16 \mathrm{~mm}$ diameter pasaran $20 \mathrm{~mm}$

3. Head loss (hf total)

Untuk menghitung kerugian gesek di dalam pipa dapat di pakai rumus sebagai berikut:

$$
\begin{aligned}
& >\mathrm{HL}=6,05 \times\left(\frac{Q^{1,85}}{C^{1,85} d^{4,87}}\right) \times 10^{5} \\
& >=6,05 \times\left(\frac{192^{1,851} / \text { menit }}{130^{1,85} \times 20^{4,87} \mathrm{~mm}}\right) \times 10^{5}=0,574 \mathrm{bar}=0,57 \mathrm{~m}
\end{aligned}
$$

4. Kecepatan aliran sebenarnya

5. Head Velocity

$$
\begin{aligned}
& >\mathrm{A}=\frac{1}{4} \times \pi \times d^{2} \\
& >\mathrm{A}=\frac{1}{4} \times \pi \times(0,032 \mathrm{~m})^{2}=0,080 \mathrm{~m}^{2} \\
& >\mathrm{V}=\frac{Q}{A}=\frac{0,032 \frac{m^{3}}{\mathrm{~s}}}{0,080 \mathrm{~m}^{2}}=0,4 \frac{\mathrm{m}}{\mathrm{s}}
\end{aligned}
$$

Head karena perbedaan tekanan pada kedua permukaan $(\Delta h p)$. Untuk mengetahui dapat dinyatakan dengan rumus:

$$
\begin{aligned}
& >\mathrm{Hv}=\frac{v^{2}}{2 \times \mathrm{g}} \mathrm{X} \\
& >\mathrm{Hv}=\frac{0,4^{2} \mathrm{~m} / \mathrm{s}}{2 \times 9,81 \mathrm{~m} / \mathrm{s}}=0,081 \mathrm{~m}
\end{aligned}
$$

6. Head Total

Head total adalah besarnya head minimal yang harus disediakan oleh pompa untuk dapat mengalirkan air sesuai dengan kondisi yang diinginkan. Dapat dihitung dengan rumus:

$$
\begin{aligned}
& \mathrm{H}=\mathrm{ha}+\mathrm{Hv}+\mathrm{h} f \text { total } \\
& \mathrm{H}=10,12 \mathrm{~m}+0,081 \mathrm{~m}+0,57 \mathrm{~m}=10,77 \mathrm{~m}
\end{aligned}
$$

7. Daya Pompa

Pompa di gunakan untuk menaikan air dari tangki atas melalui sistem perpipaan.

Dapat dihitung dengan rumus:

$$
\begin{gathered}
P=\frac{\boldsymbol{\rho} \cdot \boldsymbol{g} \cdot \boldsymbol{Q} \cdot \boldsymbol{H}}{\mathbf{8 0} \%} \\
=\frac{1000 \frac{\mathrm{kg}}{\mathrm{m}^{3}} \times 9,8 \frac{\mathrm{m}^{2}}{\text { detik }} \times 0,032 \frac{\mathrm{m}^{3}}{\text { detik }} \times 10,77 \mathrm{~m}}{80 \%}=4221,84 \mathrm{watt}=4,22 \mathrm{~kW}
\end{gathered}
$$

Maka, daya pompa yang dibutuhkan pompa yang bekerja dari booster pump untuk distribusi ke lantai 5 dan lantai 6 adalah 4,22 kW. Maka air dapat di alirkan untuk memenuhi kebutuhan lantai 5 dan lantai 6 .

\subsection{Perhitungan Diameter Pipa Tegak Air Bersih}

Pipa tegak merupakan shaft utama pada gedung ini yang mendistribusikan air ke jalur pipapipa horizontal yang menyuplai air untuk kebutuhan air gedung ini. Pada tabel 3 adalah 
akumulasi beban saluran jumlah alat plambing yang di terima oleh pipa shaft utama dari semua pipa horizontal yang berhubungan langsung dengan pipa tegak.

Tabel 3 Diameter Pipa Tegak Air Bersih

\begin{tabular}{ccccc}
\hline Lantai & $\begin{array}{c}\text { Fixture Unit } \\
\text { Akumulasi }\end{array}$ & Ubab & $\begin{array}{c}\text { Diameter } \\
\text { (inch) }\end{array}$ & $\begin{array}{c}\text { diameter } \\
\text { pasaran } \\
\text { (mm) }\end{array}$ \\
\hline Lantai 1 & 32 & 54,5 & $11 / 4$ & 40 \\
Lantai 2 & 48 & 81 & $11 / 2$ & 50 \\
Lantai 3 & 61 & 107 & $11 / 2$ & 50 \\
Lantai 4 & 74 & 133 & $11 \frac{1}{2}$ & 50 \\
Lantai 5 & 87 & 159 & $11 \frac{1}{2}$ & 50 \\
Lantai 6 & 100 & 185 & $11 / 2$ & 50 \\
\hline
\end{tabular}

Sumber : SNI 8153-2015

Keterangan : UBAP (unit beban alat Plambing)

Pipa yang lebih besar akan lebih baik karena akan memperpanjang umur pipa dan dapat menambah sedikit beban bila sewaktu-waktu diperlukan penambahan alat plambing. Pada umumnya pipa tegak akan terpasang jauh lebih besar dari hasil perhitungan, hal ini dapat mengurangi biaya konstruksi karena akan mengurangi penggunaan aksesoris pipa sehingga secara tidak langsung dengan berkurangnya penggunaan aksesoris, maka akan mengurangi biaya konstruksi.

\subsection{Perhitungan Dimensi Pipa Air Bersih}

Perhitungan dimensi pipa air bersih dilakukan setelah mengetahui jumlah kebutuhan alat plumbing. Alat plambing yang membutuhkan air bersih berdasarkan ubab dari SNI03-70652005. Pada gedung alat plambing yang digunakan yaitu. Water Closet (WC) Ubab 2,5, Faucet (FC) ubab 3, Kitchen Sink (KS) ubab 3, Urinoir (UR) ubab 2, Shower (SH) ubab 2, dan Lavatory (LV) ubab 2. Setelah di dapat nilai ubab setiap alat plambing di sesuaikan dengan SNI03-7065-2005. Tabel 4 halaman 32 di dapat diameter pipa yang di gunakan. Pipa pasaran yang digunakan yaitu pipa PPR (Polypropylene Random). 


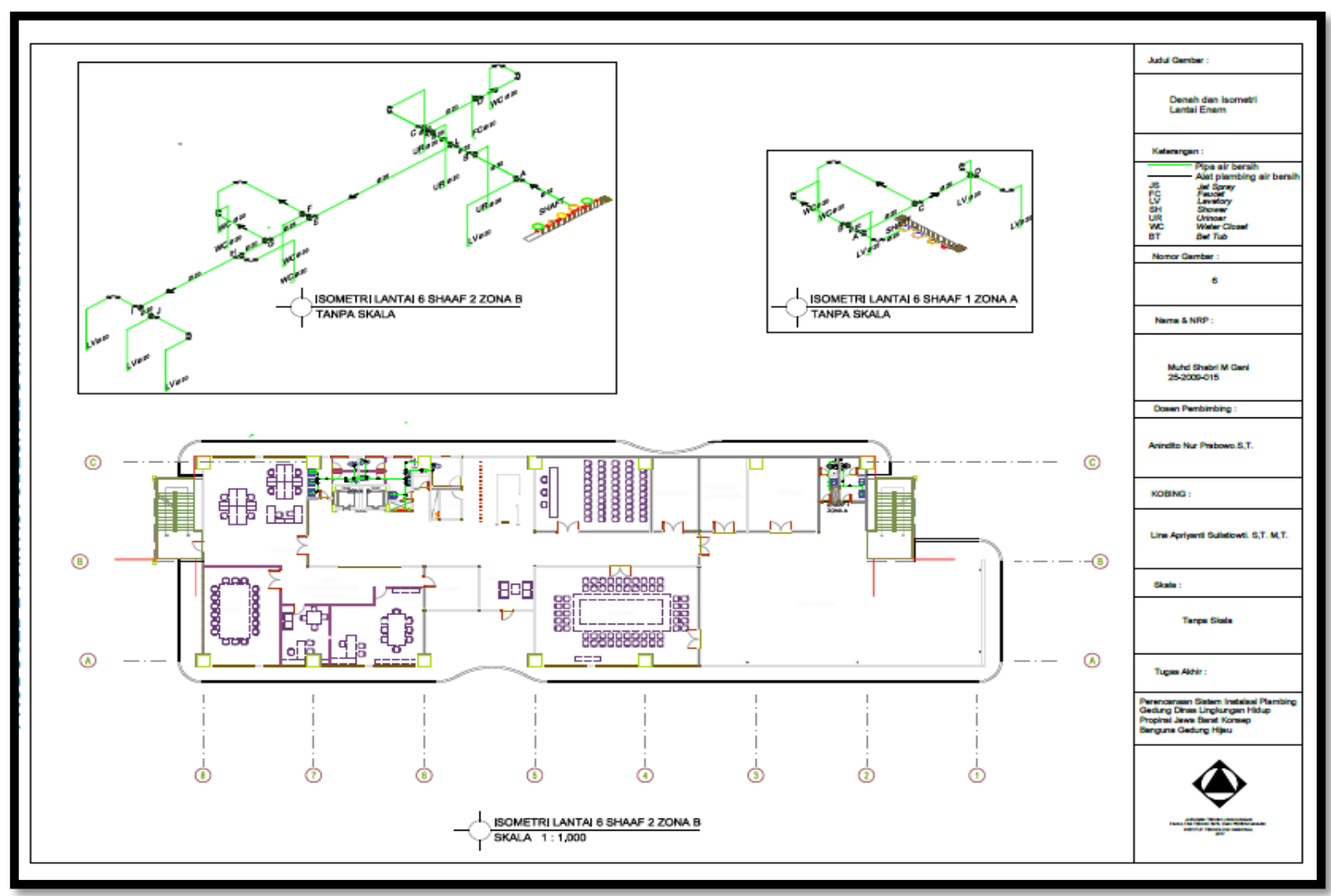

Gambar 3 Denah dan isometri lantai 6

\section{KESIMPULAN}

Sistem distribusi yang digunakan adalah sistem aliran kebawah yang berasal dari roof tank. Distribusi dilakuakan dengan memanfaatkan gaya gravitasi untuk lantai 6 sampai lantai 1 dan dengan menggunakan bantuan pompa booster untuk distribusi air bersih lantai 5 dan lantai 6. Jumlah populasi pada gedung Kantor Dinas Lingkungan Hidup Propinsi Jawa Barat adalah 654 orang dengan total kebutuhan air bersih sebesar $29,3 \mathrm{~m}^{3} /$ hari. Kapasitas ground water tank yang tersedia $31,5 \mathrm{~m}^{3}$. Hasil tersebut adalah didapatkan dengan menggunakan debit harian untuk kebutuhan air bersih. Maka, kapasitas GWT memenuhi untuk kebutuhan air bersih dalam sehari. Kapasitas roof tank adalah 33,15 $\mathrm{m}^{3}$. kapasitas roof tank dapat memenuhi kebutuhan pada jam puncak.

\section{DAFTAR RUJUKAN}

Neufert, E. (2002). Data Arsitek. Dalam H. W. Hardani (Penyunt.). Jakarta: Erlangga.

Noerbambang, M. S., \& Morimura, T. (2005). Perancangan dan Pemeliharaan Sistem Plambing. Jakarta: Pradnya Paramita.

SNI03-7065-2005. (2005). Tata Cara Perencanaan Sistem Plumbing.

SNI 8153- 2015 Tentang Sistem Plambing pada Bagian Gedung.

Peraturan Walikota Bandung tahun 2016 Tentang Bangunan Gedung Hijau. 